\title{
植物の形状と大きさおよび設置距離が室内植物の印象 評価に及ぼす影響
}

\author{
Influences of the Plants' Shape, Size, and Distance to the Estimator on the Impression Evaluation of \\ the Indoor Plant
}

\author{
長谷川祥子* 下村＼cjkstart孝* \\ Shoko HASEGAWA Takashi SHIMOMURA
}

\begin{abstract}
We made an impression evaluation experiment to clarify the psychological evaluation of the small interior plant comparing to a midsize or a large plant. Two types of plants, i.e., Kokedama-styled plants and potted plants were used for the experiment. Kokedama-styled plant is a small herbaceous plant or a small tree which is planted in a rounded growing medium lapped with thin-layer of moss. It has been expected to become popular as a small interior plant in Japan. The potted plant has been used as conventional interior plants in experiments to study this subject. The semantic differential method showed clearly that a small kokedama-styled plant was different from a large potted plant in impression with feature, size and distance to the estimator. And it was also suggested that when a just small kokedama-styled plant was prepared in its most suitable combinations and also placed in an appropriate distance, it could give people a good impression in well-being and affinity, as if a midsize or a large plant did.
\end{abstract}

Keywords: interior plant, kokedama, foliage plants, semantic differential method, evaluation of impression キーワード：室内植物, 苔玉, 観葉植物, SD 法, 印象評価

\section{1.はじめに}

人の生活と環境の関わりを考察した教育哲学者の O. F. ボル ノー ${ }^{1)}$ は, 自然から疎外された都市では, 生命が持つ生動性は危 機に瀕しており, 文化を作り上げていく中で自然への結びつきを もう一度取り戻すことが必要であると述べている。そして, 都市 内部に緑を持ち込む空間として, 公園や道路さらには建築物の内 部空間などを挙げている。都市の緑環境の悪化や住宅事情の変化 などにより, 室内緑化は, 都市生活の身近に緑を持ち込む手段と して重要性を増してきている ${ }^{2)}$ 。そのため, 住宅 ${ }^{3), 4)}$ や職場 ${ }^{5)}$, 商業施設 ${ }^{6)}$ など多様な空間で室内植物が利用されるようになった。

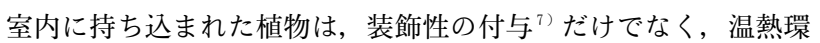
境改善 ・ 快適性向上効果 $\left.{ }^{8)},{ }^{9}\right)$ や空気浄化効果 ${ }^{10)}$ あるいは防火効 果 ${ }^{11)}$ などの物理的, 化学的効果をむたらす。また, 植物がある居 室の印象は肯定的に評価される ${ }^{12)}$ 。さらに，作業の間に植物を見 ることで視覚疲労 ${ }^{13)}$ や身体的苦痛が軽減し ${ }^{14)}$, ストレスや緊張感 屯緩和され ${ }^{15)}$, 職場での身体的不調が軽減すること ${ }^{16)}$ など, 人間 の心理や生理への影響屯明らかにされている。

従来, 室内には, 主に中〜大型の鉢植え観葉植物が持ち込まれ て利用されてきた。しかし近年, ミニ盆栽やハイドロカルチャー システムなどのミニ観葉, 苔玉などの小型室内植物が, 園芸店だ けでなく, 生活雑貨店などでも販売され ${ }^{17)}$, 普及の兆しがみられ ている。これらの小型室内植物は, 装飾性が高く, 園芸愛好家だ けでなく，インテリア素材として植物を置きたいと考える人のニー ズにも応えている ${ }^{18)}$ 。また, ミ二盆栽や苔玉には, 観葉植物に限 らず，山野草など多様な植物が用いられている。さらに，オフィ スのデスクに個人が小型の植物を持ち込むようにもなってきてい る ${ }^{19)}$ 。こように, 室内で用いられる植物は, 大きさや形態, 植 物の種類, 利用形態などの点で多様化する傾向を示している。

上述の室内植物による環境改善効果や人間の心身への影響は, 中型や大型の鉢植え観葉植物を用いて検証されており, 近年普及 し始めている多様な室内植物の影響に関する研究は，少ない ${ }^{17)}, 200$
一方で, 室内植物による心理的影響は, 植物の種や配置方法によっ て異なるとの報告があり ${ }^{12)}$, 人間への植物の心理的影響が多様な 植物の間で異なる可能性も想定できる。したがって, 多様な室内 植物と中大型観葉植物の心理的評価を試み, それぞれの心理的影 響を比較検討することが望まれる。

浅海ら ${ }^{12}$ は, 室内植物の印象は, 植物の種によって異なること を明らかにしている。このことから, 種の違いによってもたらさ れる葉の形や量, 樹形などの外観の違いが評価に影響をむたらす のではないかと推測できる。鉢植え植物の鉢や苔玉の玉部などの 地下部む外観を構成する要素であり, それらと植物が生み出す鉢 植えや苔玉という形態 (以降, 用語「形態」をこの主旨で使用す る）の外観の違いが印象評価に影響を及ぼすとの予測も可能であ る。従来多用されてきた鉢植えとは異なる形態が普及しつつある 現在, 植物種による影響だけでなく, 室内植物の形態が印象評価 に及ぼす影響を明らかにすることも必要であると考えられる。

日本庭園と西洋庭園を含む庭園景観のイメージ評価では, 整形 式の西洋庭園景よりも日本庭園や露地, 坪庭といった日本独特の 庭園景に癒しを感じる学生が多いことが示された ${ }^{21}$ 。庭園の様式 も印象評価に影響を及ぼす要因であることが示唆されたと考えら れる。苔玉やミ二盆栽は, コケが用いられ, さらに観葉植物だけ でなく和風の植物が利用されるために, 和風の雾囲気を備えてい ると評価されている ${ }^{22)}$ 。一方, 鉢植えの室内植物は, 主に観葉植 物を用いており, 洋風のイメージが強いと考えられる。室内植物 を「形態」と「植物」に分けて考えた場合, 形態に調和する植物 の様式が異なる可能性も想定される。そこで, 室内植物を構成す る植物と形態の様式の調和が心理的評価に及ぼす影響を把握する ことは実用上も有益である。

住宅の価值評価に及ぼす庭園の影響を調査した研究によって ${ }^{23)}$, 庭園を構成する要素は, 植物の生態型（常緑と落葉など）, 植物 の大きさ，庭園のデザイン性の順に住宅の価值に大きな影響を及 ぼすことが示された。小さな植物を用いるよりも，大きな植物を 
用いた場合に, 住宅の価值が消費者に高く評価された。この研究 は，屋外景観を対象にした研究であるが，室内でも多様な大きさ の植物が利用されるようになっている。植物の大きさむ室内植物 の印象に影響を及ぼすと予測されるが，大きさごとに植物の印象 を比較検討した研究事例は見られない。室内植物の大きさが印象 評価に及ぼす影響を把握することが必要であると考えられる。

Bringslimark et al. ${ }^{24)}$ は, 職場において, 個人のワークスペー ス内の植物を個人化された私的な植物として, 離れた場所にある 植物と区別して考察する視点を提起している。職場の卓上など, ワーカーの身近に置かれた小型植物は, この「私的」な植物とみ なすことが可能といえる。小型植物を身近に設置する際, その植 物をワーカー自身が選択した時のほうが，選択しない場合に比べ， 当該植物に対する満足感が高いとの報告がある20)。さらに, 置い た植物の世話をした場合は, しない場合に比べ, 今後の利用意欲 が強くなった ${ }^{20)}$ 。れらの研究結果は, 身近で私的に利用するこ とで小型植物による影響が増大する可能性を示唆している。一方, 戸外の研究によれば，都市公園の樹木は，同一の樹木であっても， 見る距離によって, 開放性や親密感などの評価に違いが認められ ている ${ }^{25)}$ 。しかし, 室内空間における, 植物と人間との距離に関 する検討 ${ }^{20), 24)}$ は, 実際のオフィスで利用されている植物を対象 としているため, 距離の異なる同一の植物の間の比較は行われて おらず, 設置距離の詳細な影響は明らかにされていない。小型植 物は, 人の身近に設置可能であり, 室内における人と植物との距 離が印象に及ぼす影響の調査は重要である。

以上のように, 既往研究から, 形態や大きさなどの室内植物の 多様性は, 室内植物の心理的評価に影響を及ぼすと予測される。 しかし, これらの課題を明らかにした研究事例は未だ見出されて いない。また, 室内植物の印象は, 設置する室内の様式にも影響 を受けると考えられる。したがって，本研究では，まず，オフィ 又等の比較的単調で無機質な空間における室内植物利用を想定し た条件を設定し, 室内植物を構成する形状 (形態と様式), 大き さおよび設置距離の各要因が心理的評価に及ぼす影響を調べた。 その結果から, 今後, 多様な室内植物を利用する際の植物の形状 や大きさおよび設置距離などに関する基礎的な知見を得ることを 目的とした。

\section{2. 研究方法}

\section{(1) 実験の要点}

本研究では, 評価対象の植物の実物を評定者に呈示し（詳細は 後述), SD 法に基づく印象評価実験を行った。

\section{（2）要因と水準}

要因を植物の形態, 植物の様式, 大きさおよび評定者と評価対 象との間の距離（以降，「設置距離」をこの意で用いる）とした。 植物の形態は, 鉢植えと苔玉の 2 水準とした。苔玉は, 植物を鉢 などの容器に植えず, 根を用土でくるみ, その表面にコケを張っ て仕立てたものとされる ${ }^{222}$ 。個人住宅での利用は 10 年程前には じまり, 室内植物としての利用頻度は, 鉢植え植物, サボテンに 次いでいる ${ }^{3)}$ 。また，「見た目」や「置きやすさ」に対する評価 が高く, 身近で利用する小型室内植物として今後の普及が見込ま れる ${ }^{3)}$ 形態の一種である。植物の様式は, 和風と洋風の 2 水準, そして大きさは小, 中および大の 3 水準, さらに, 設置距離は, オフィス内の植物の質的分類 ${ }^{24}$ を参考に, 個人のワークスペース 内のデスクの上などの植物を想定した近 $(0.5 \mathrm{~m})$, 個人のワーク スペース付近の手の届かない範囲を想定した中（1.5m）および 個人のワークスペースの外にあるオフィス内の植物を想定した遠 （３ｍ）の3 水準をそれぞれ設けた。これらを組み合わせた評価 対象の設定は 36 通りとなり, これに評価主体を評定作業に馴染 ませるためのダミーを加えた全 37 通りとした。

\section{（3）実験に使用した植物}

植物の様式を実験要因とし, 和風および洋風を水準に定めたた め, これら 2 様式の本実験での定義付けを行った。大辞泉（小学 館）には, 和風は「日本古来の風俗・様式。日本風。日本式。和 式。」, 洋風は「西洋的な形式であること。洋式。西洋風。」と記 載されている。しかし，これらを植物に当てはめた印象の定義は 見られない。そこで, 植物を利用する庭園の様式に関する定義を 見ると, 日本（和風）庭園は自然式，一方，西洋式（洋風）庭園 は幾何学式，整形式とされることが多い26)。本実験では，この観 点に準じ, 自然樹形を持つ植物を和風, 整形式樹形を持つ植物を 洋風と位置づけた。和風には, 自然樹形を持ち, 「日本的樹形で 風情がある27)」とされるイロ八モミジ（Acer palmatum，以下 モミジと略記), 洋風には, 整形式樹形を持ち, 「洋風で観賞価値 が高い針葉樹 ${ }^{28} 」$ とれるコニファーの中でも，観葉鉢物として 最も普及している品種である ${ }^{28)}$ ゴールドクレスト（Cupressus macrocarpa 'Gold Crest', 以下クレストと略記) を用いた（写 真一 1)。ただし, 本研究は夏季に実施した実験によるものであ り, 落葉するモミジの冬季利用に関しては, 把握できていない。

なお，鉢植え植物は大きさに応じた竹製の鉢カバーに入れ，苔 玉には竹製の敷物を敷いた。小型は高さ $70 \mathrm{~cm}$ ，中型は高さ $58.5 \mathrm{~cm}$ の台の中央に, さらに大型はフロア上に置いた。実験に 使用した植物の概要は，表一 1 に示す通りである。

\section{(4) 実験の方法}

実験は, 京都府立大学 $\mathrm{RC}$ 造 3 階建てビル 3 階の会議室（東西 $8.5 \mathrm{~m} \times$ 南北 $7 \mathrm{~m}$ ，北面はガラス空）内で, 2008 年 6 月 16 日から 7 月 15 日の間に行った。評価者は, 室内植物についての専門知 識を持たない京都府立大学の学部生および院生（41名）であっ た。なお，北側の空にはカーテンを引いて外部の景色が見えない ようにした。実験室の平均気温 $\left({ }^{\circ} \mathrm{C}\right)$, 平均相対湿度 $(\% \mathrm{RH})$ は, $27.3^{\circ} \mathrm{C} ， 64.5 \% \mathrm{RH}$ であった。 $\mathrm{SD}$ 法に用いる形容詞は, 観 葉植物の印象評価 ${ }^{5)}, 12$, 部屋の印象に与える観葉植物の影響 ${ }^{12}$ 等 の既往研究を参考に, 15 の形容詞対を選択して, 7 段階評価とし た。乱数発生によりランダムに形容詞対を配置し，また形容詞の 両極の左右性も無作為に位置づけた 37 通りの評価用紙を作成し, すべての評定者に用いた（図一1）。

実験は, 評価者 1 名ごとに行った。実験室内に机と椅子を設置 し, 評価者に着席した体勢で評価を求めた。評価者には, 30 秒 間対象を観察した後，右に 90 度回転し，60 秒間で卓上の評価用 紙に記入するよう求めた。実験者は, 評価時間内に植物の入れ替

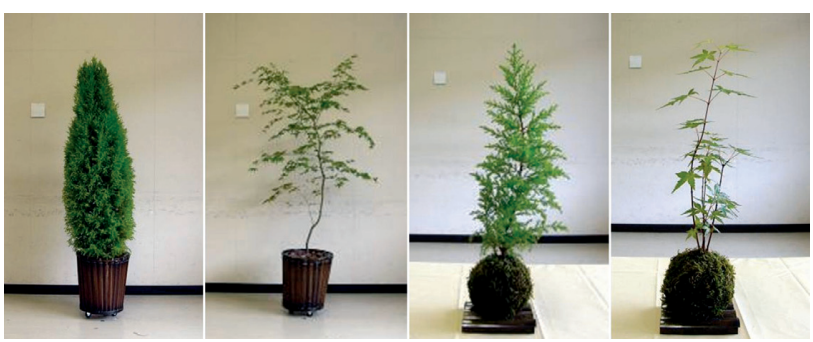

写真 -1 評価対象の例（左から，大型クレスト鉢植え，大型モ ミジ鉢植え，小型クレスト苔玉，小型モミジ苔玉）

表 -1 実験に使用した植物の概要

\begin{tabular}{cccccc}
\hline 苔玉 & $\begin{array}{c}\text { 樹高 } \\
(\mathrm{m})\end{array}$ & $\begin{array}{c}\text { 玉部直径 } \\
(\mathrm{cm})\end{array}$ & 鉢植え & $\begin{array}{r}\text { 樹高 } \\
(\mathrm{m})\end{array}$ & $\begin{array}{c}\text { 鉢サイズ } \\
(\text { 号 })\end{array}$ \\
\hline 小型モミジ & 0.34 & 8 & 小型モミジ & 0.28 & 4 \\
中型モミジ & 0.50 & 15 & 中型モミジ & 0.50 & 6 \\
大型モミジ & 1.30 & 28 & 大型モミジ & 1.30 & 10 \\
小型クレスト & 0.34 & 8 & 小型クレスト & 0.38 & 4 \\
中型クレスト & 0.55 & 15 & 中型クレスト & 0.60 & 6 \\
大型クレスト & 1.30 & 28 & 大型クレスト & 1.30 & 10 \\
\hline
\end{tabular}




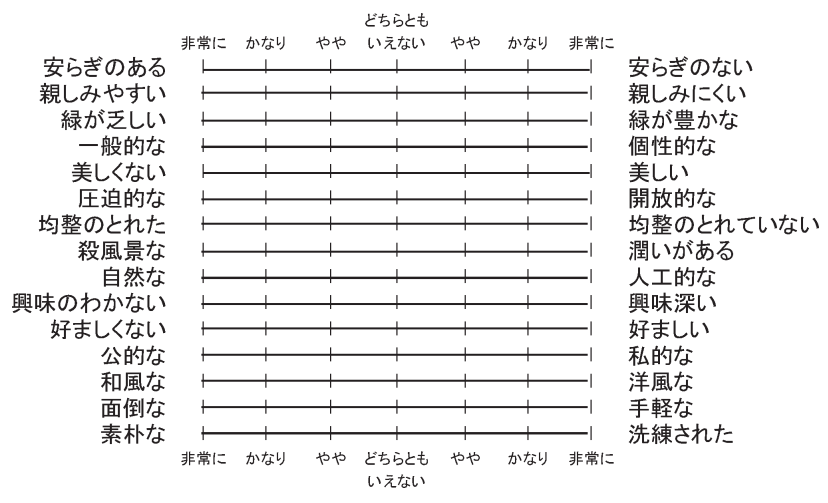

図-1 評価用紙の例

えを行い, 60 秒後に評価者に対し, 再度左 90 度回転し, 植物を 観察するように求めた。37 通りの対象を評価するのに要した時 間は平均で 1 時間 15 分であった。また, 評価対象の呈示順は, 順序効果を避けるため, 実験ごとに乱数発生によるランダムな順 で呈示した。なお，評価者には適切と判断できる謝金を支払った。 (5) 分析方法

欠損值のあった 1 名分のデー夕を除き, 40 名のデー夕を分析 の対象とした。評価対象ごとの評価の特徴を調べるために, 得ら れた評定結果の否定側を 1 , 肯定側を 7 とした 7 段階の得点化を 行った。得点化した評価得点は, 順序尺度データではあるものの, 経験的に間隔尺度データとみなすことに大きな問題がないとの見 解があるため ${ }^{29}$, 本研究では, 間隔尺度データとみなして, 分析 に用いた。

評価得点に及ぼす被験者内 4 要因の影響を検定するために，代 用的に，パラメトリック検定である分散分析，および，有意であっ た場合には交互作用の分析を行った（有意水準 $5 \%$ または $1 \%$ ）。 また, 大きさと設置距離に単純主効果が見られた場合には, LSD 法による 3 群の平均值の比較を行った（有意水準 $5 \%$ ）。

測定データの統計処理には，表計算ソフトの Excel 2007 (Microsoft Inc.) および統計処理ソフトの STATISTICA 6 (StatSoft Inc.) を用いた。

\section{3. 結果および考察}

\section{（1）実験参加者の属性}

（i ）性別および年令

分析対象の評定者の性別は，男性 16 名，女性 24 名であった。 また年齢は $18 \sim 25$ 歳であり, 平均年齢は, 21.03 歳（標準偏差 1.99, $\mathrm{n}=40$ ) であった。

\section{(ii）苔玉の認知}

苔玉を知っている評定者は 55\%で，名前を知っている，見か けたことがあるが知らないを合わせると $85 \%$ となった。見たこ ともなく，まったく知らない評定者は $15 \%$ に留まった（表－2）。 （iii）植物抒よび苔玉への興味

植物および苔玉に対する興味と関心の程度を 5 段階で評価を求 めた。その結果，いずれに対しても興味と関心が全然ないとする 回答は皆無で，大いにあるとややありの回答を合わせると，いず れも，90\%弱となった（表－3）。植物全般同様に，苔玉にも関 心を持つ評定者が多いと判断された。

\section{（2）評価得点に対する実験要因の影響}

植物の形態, 様式, 大きさおよび設置距離の要因が印象評価に 及ぼす影響を知るために, 被験者内 4 要因の分散分析を行い, 各 形容詞対の評価得点平均值の差の有意性を検定した。その結果, 公私において形態の主効果 $(\mathrm{F}(1,39)=18.38, \mathrm{p}<.01)$ および和風 洋風において距離の主効果 $(\mathrm{F}(2,78)=7.18, \mathrm{p}<.01)$ が, さらに
表 -2 苔玉の認知状況 $(n=40)$

\begin{tabular}{lr}
\hline 回答項且 & 回答数 $(\%)$ \\
\hline 知っいる & $22(55.0)$ \\
名前は知っている & $2(5.0)$ \\
見かけたことはあるが知らない & $10(25.0)$ \\
知らない & $6(15.0)$ \\
\hline 総数 & $40(100)$ \\
\hline
\end{tabular}

表ー $3 \quad$ 植物および苔玉に対する関心 $(n=40)$

\begin{tabular}{lrr}
\hline 回答項目 & \multicolumn{1}{c}{ 植物 $(\%)$} & \multicolumn{1}{c}{ 苔玉 $(\%)$} \\
\hline 大いああ & $8(20.0)$ & $7(17.5)$ \\
まあまあある & $27(67.5)$ & $28(70.0)$ \\
よ゙ちらとも言えない & $3(7.5)$ & $2(5.0)$ \\
あまりない & $2(5.0)$ & $3(7.5)$ \\
全然ない & $0(0.0)$ & $0(0.0)$ \\
\hline 総数 & $40(100)$ & \multicolumn{1}{c}{$40(100)$} \\
\hline
\end{tabular}

表一４交互作用が有意であった項目

項目 1 次の交互作用 F值

美しい 形態 $\times$ 様式 $F(1,39)=40.60^{* *}$ 形態 $\times$ 大きさ $F(2,78)=20.86^{* *}$ 様式 $\times$ 大きさ $F(2,78)=41.65^{*}$ 大きさ $\times$ 距離 $F(4,156)=9.04^{* *}$

洗練形態 $\times$ 様式 $F(1,39)=25.01^{* *}$ 形態 $\times$ 大きさ $F(2,78)=12.23^{* *}$ 様式 $\times$ 大きさ $F(2,78)=13.04^{* *}$ 形態 $\times$ 距離 $\quad \mathrm{F}(2,78)=3.35^{*}$ 様式 $\times$ 距離 $\quad F(2,78)=3.57^{*}$

和風洋風形態 $\times$ 様式 $F(1,39)=10.60 * *$ 様式 $\times$ 大きさ $F(2,78)=23.09^{* *}$

潤い 形態 $\times$ 様式 $\quad F(1.39)=18.35^{* *}$ 形態 $\times$ 大きさ $F(2,78)=9.01^{* *}$ 様式 $\times$ 大きさ $F(2,78)=21.00^{* *}$ 様式 $\times$ 距離 $\quad F(2,78)=8.22^{* *}$ 大きさ $\times$ 距離 $\quad F(4,156)=9.18^{* *}$ 形態 $\times$ 様式 $\quad F(1,39)=19.46^{* *}$ 形態 $\times$ 大きさ $F(2,78)=17.98^{* *}$ 様式 $\times$ 大きさ $F(2,78)=12.06^{* *}$ 大きさ $\times$ 距離 $F(4.156)=5.57^{* *}$ 形態 $\times$ 距離 $\quad F(2,78)=4.78^{*}$

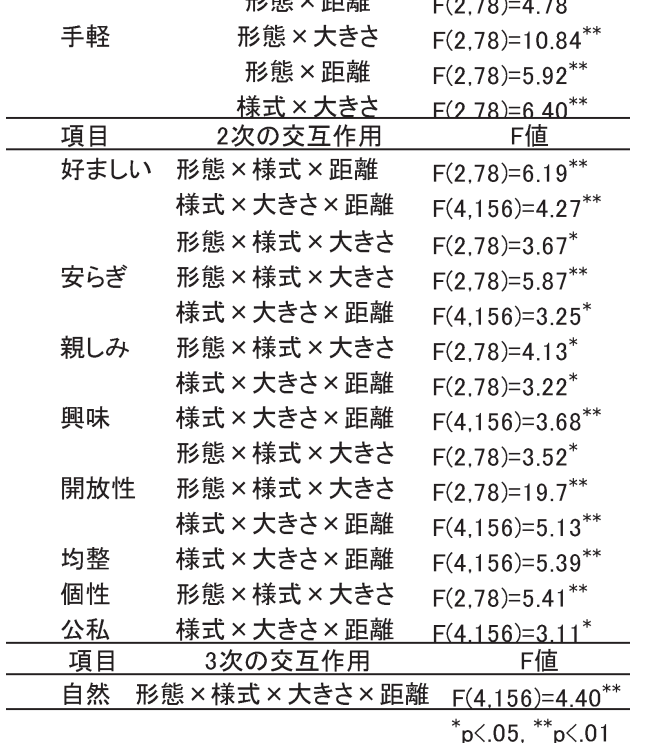

表 -5 様式の水準ごとの苔玉と鉢植えの平均值

\begin{tabular}{|c|c|c|c|c|c|c|}
\hline \multirow{2}{*}{ 項目 } & \multicolumn{3}{|c|}{ 水準「和風」 } & \multicolumn{3}{|c|}{ 水準「洋風」 } \\
\hline & 苔玉 & 鉢植え & & 苔玉 & 鉢植え & \\
\hline 美しい & 5.46 & 4.49 & ** & $3 . \overline{98}$ & 4.51 & ** \\
\hline 洗練 & 4.59 & 3.61 & ** & 3.89 & 3.78 & ns \\
\hline 和風洋風 & 6.14 & 5.17 & ** & 3.89 & 2.48 & ** \\
\hline 潤い & 5.09 & 3.93 & ** & 4.98 & 4.44 & ** \\
\hline 緑量感 & 4.93 & 3.89 & ** & 5.29 & 4.80 & ** \\
\hline 手軽な & 3.48 & 4.39 & - & 3.53 & 4.56 & - \\
\hline
\end{tabular}


美しさ, 洗練, 和風洋風, 潤い, 緑の豊かさ, 手軽さの 6 つの形 容詞対で 1 次の交互作用, 好ましさ, 安らぎ, 親しみ, 興味, 開 放性, 均整, 個性, 公私の 8 対で 2 次の交互作用および自然の 1 対で 3 次の交互作用が，それぞれ，有意に認められた（表一 4 )。 この結果から, 室内植物の印象の多くの評価には, 2 つ以上の要 因が相互に関連しあい，影響を及ぼしていることが明らかになっ た。特に, 室内植物の自然性の評価では 3 次の交互作用が有意で あり, 非常に複雑に, 今回設定した形態と様式, 大きさおよび設 置距離の 4 要因が関連しあっていると判断された。そのため, 自 然性を除く, 1 次および 2 次の交互作用が認められた要因ごとに, 設定された水準を取り出し, 下位検定をおこない, 各水準におけ る評価得点への要因の影響を個別に検討した。詳細は以下に示す。 な扔，デー夕表記の際は，交互作用が有意でなく，水準間に有意 な差が認められなかった項目についても，差が見られなかったこ とを示すため, 平均值のデー夕を表示した。

\section{（３）評価得点への各要因の影響}

\section{(i ) 室内植物の形態が印象評価に与える影響}

本研究で用いた苔玉と鉢植えは, 球状と鉢型という植物の地下 部の形状の違い, そして, コケとタケ（鉢カバー）という素材の 違いがある。それらの違いが, 室内植物の印象に及ぼす影響を検 討した。その結果, まず公私の評価で, 苔玉（4.55）は鉢植え （3.99）よりも私的であると評価された $(\mathrm{n}=720)$ 。そして, 公私 と均整の評価を除く形容詞対に対して交互作用が有意であった。 したがって, 形態は, 植物の様式や大きさ, 設置距離などの他の 要因とともに多くの印象評価に作用していると理解された。そこ でまず，苔玉と鉢植えの形態の影響を様式および大きさの要因内 の水準ごとに検討した。

各様式拉よび大きさの双方の水準で, 苔玉が鉢植えよりも緑が 豊かで，潤いがあり（表一 $5 ， 6$ ），個性的之評価された（表一 7, 8 )。大型クレストを除き, 他の水準では, 苔玉の方が興味 深いと評価された（表一 7，8）。モミジを用いた場合も，クレ ストを用いた場合も, 錸植えよりも苔玉が和風で（表一 5 ）, ど の大きさでも，鉢植えが手軽であると評価された（表一6）。た だし, 大きさの各水準での和風洋風の評価得点には形態間で有意 な差は見られなかった（表一6）。

美しさや洗練性による外観の評価では，植物の影響が大きく， モミジを用いた場合には, 美しさおよび洗練性は苔玉が鉢植えを 有意に上回った。一方，クレストの場合には，美しさは鉢植えが 苔玉を有意に上回ったが，洗練性には形態による影響が見られな かった（表一 5 )。また，大きさによる影響もみられ，小型およ び大型では苔玉が鉢植えより洗練性が高く, さらに, 小型では苔 玉が鉢植えより美しいと評価されたが，その他の大きさでは有意 な差は見られなかった（表一6）。

上記に加えて, 様式と大きさごとに, 好ましさや親しみ, 安ら ぎ感の評価が異なった（表一 7, 8)。モミジを用いた場合, 小 型抒よび中型では, 苔玉と鉢植えの評価得点の間に有意差が見ら れ, 苔玉の評価が鉢植えを凌いだ。一方, 大型では, 苔玉と鉢植 えともに評価が高く有意差は見られなかった。クレストを用いた 場合, 中型および大型では鉢植えが苔玉より好ましく, 小型およ び中型では鉢植えが苔玉より親しみやすいと評価された。

以上のように，まず，苔玉は鉢植えよりも緑が豊かであると評 価された。苔玉，鉢植え両形態ともに，用いた植物の大きさが同 程度であるにも拘わらずこのように評価されたのは，苔玉では， 地下部を玉型に覆うコケがあり, 視野内の緑の面積を増加させた ことが影響したと考えられた。また，そのコケが潤い感の評価に も肯定的な影響を及ぼしたと考えられる。さらに，いずれの様式 の植物を用いた場合にも, 鉢植えに比べ, 苔玉の方がより和風で あると評価された。コケが日本庭園を連想させたりすることによっ
て，和風であるとの判断を招いたのではないかと推測された。こ れらは, 苔玉と鉢植えの素材が異なることによる影響であると考 えることも可能である。しかし，大，中，小のいずれの場合も， 苔玉と鉢植えの間に和風洋風の評価得点の有意な差が見られなかっ た。これらの結果から, 苔玉と鉢植えの形態よりも, 植物の様式 （和風・モミジ，洋風・クレスト）による影響が大きかったと考 えられた。さらに，苔玉は錸植えよりも個性的で，興味深い之評 価されることが多かった。これは，苔玉の基部の形状が一般的な 鉢などとは異なり，有機体のコケで包まれていることによると考 えられた。樹形や葉の形といった植物の姿（外観）が，印象に影 響を与えることが明らかにされている ${ }^{12)}$ が，視覚要因としての栽 培形態も印象に影響を与えると判断された。一方で，和風植物の 場合に，苔玉の方が美しく，洋風植物の場合には鉢植えの方が美 しいと評価され，また，好ましさや親しみやすさも植物の様式お よび大きさによって変化した。すなわち，様式を表す植物および 大きさごとに適する形態が異なることが示唆されたと言える。形 態ごとの植物の様式の影響や大きさの影響は, 次項で検討した。

なお, 設置距離および様式の水準で, 形態の影響が有意であっ た項目は, 洗練性, 緑量感, 手軽さおよび好ましさのみであり, それらに対する形態間の評価の差は, 様式および大きさの水準で の検討結果とほぼ同様の傾向を示した (デー夕略)。

本実験結果から, 一定の条件下で, 栽培形態によって緑量感や 和風洋風の判断，美しさや洗練性などの外観評価などに影響がみ られることが明らかになった。一方, 均整の評価には形態の要因 は影響を及ぼさないことが示された。

\section{（ii）植物の様式が印象に与える影響}

苔玉と鉢植えごとに用いる植物の様式が印象に与える影響を検 討した。和風植物にイロ八モミジ，そして，洋風植物にはゴール ドクレストを用いた。種は植物の外観の違いを生む要因となり, 種に応じて様式, 樹形, そして, 緑量に差異が生じ得る。まず, 大きさの 3 水準抢よび距離の 3 水準内での評価得点の平均值の比 較により, モミジ（和風）とクレスト（洋風）双方の特性を把握

\begin{tabular}{|c|c|c|c|c|c|c|c|c|c|}
\hline \multirow{2}{*}{ 項目 } & \multicolumn{3}{|c|}{ 水準「小型」 } & \multicolumn{3}{|c|}{ 水準「中型」 } & \multicolumn{3}{|c|}{ 水準「大型」 } \\
\hline & 苔玉 & 鉢植え & & 苔玉 & 鉢植え & & 苔玉 & 鉢植え & \\
\hline 美しい & 4.99 & 4.15 & ** & 4.55 & 4.62 & ns & 4.60 & 4.72 & ns \\
\hline 洗練 & 4.10 & 3.15 & ** & 4.08 & 3.79 & ns & 4.55 & 4.14 & ** \\
\hline 和風洋風 & 5.07 & 3.81 & - & 5.05 & 3.84 & - & 4.93 & 3.82 & - \\
\hline 潤い & 4.81 & 3.59 & ** & 4.96 & 4.30 & ** & 5.33 & 4.66 & ** \\
\hline 緑量感 & 4.51 & 3.51 & ** & 5.20 & 4.26 & ** & 5.62 & 5.27 & ** \\
\hline 手軽な & 4.05 & 5.08 & ** & 3.47 & 4.73 & ** & 2.99 & 3.62 & ** \\
\hline
\end{tabular}

\section{表- 7 大きさの水準別の苔玉と鉢植えの平均值（和風）}

\begin{tabular}{|c|c|c|c|c|c|c|c|c|c|}
\hline \multirow{2}{*}{ 項目 } & \multicolumn{9}{|c|}{ 水準 $\lceil$ 和風・小型」水準 $\Gamma$ 和風・中型」水準 $\Gamma$ 和風・大型」 } \\
\hline & 苔玉 & 鉢植え & & 苔玉 & 鉢植え & & 苔玉 & 鉢植え & \\
\hline 好ましい & 5.18 & 3.79 & ** & 5.04 & 4.40 & ** & 5.30 & 4.93 & ns \\
\hline 安らぎ & 5.29 & 3.90 & ** & 4.98 & 4.45 & ** & 5.09 & 5.02 & ns \\
\hline 親しみ & 5.00 & 3.98 & ** & 4.70 & 4.38 & ns & 4.80 & 4.82 & ns \\
\hline 興味 & 5.29 & 3.59 & ** & 5.23 & 4.13 & ** & 5.43 & 4.67 & ** \\
\hline 開放性 & 5.23 & 5.13 & ns & 4.25 & 4.53 & ns & 4.00 & 4.39 & $T$ \\
\hline 均整 & 5.05 & 3.85 & - & 4.77 & 4.30 & - & 5.05 & 4.43 & - \\
\hline 個性 & 4.88 & 3.65 & ** & 4.75 & 3.63 & ** & 4.70 & 3.73 & ** \\
\hline
\end{tabular}

${ }^{*} \mathrm{p}<.05,{ }^{* *} \mathrm{p}<.01, \mathrm{n}=240$

表- 8 大きさの水準別の苔玉と鉢植えの平均値（洋風）

\begin{tabular}{|c|c|c|c|c|c|c|c|c|c|}
\hline \multirow{2}{*}{ 項目 } & \multicolumn{9}{|c|}{ 水準「洋風・小型」水準「洋風・中型」水準「洋風・大型」 } \\
\hline & 苔玉 & 鉢植え & & 苔玉 & 鉢植え & & 苔玉 & 鉢植え & \\
\hline 好ましい & 4.53 & 4.71 & ns & 3.82 & 4.63 & *** & 3.44 & 3.92 & \\
\hline 安らぎ & 4.66 & 4.71 & ns & 4.28 & 4.56 & ns & 3.81 & 4.08 & - \\
\hline 親しみ & 4.42 & 4.93 & * & 3.94 & 4.69 & ** & 3.47 & 4.09 & - \\
\hline 興味 & 4.68 & 4.02 & ** & 4.37 & 3.82 & * & 4.09 & 3.60 & - \\
\hline 開放性 & 4.63 & 4.93 & ** & 4.27 & 4.48 & ns & 3.29 & 2.78 & ** \\
\hline 均整 & 4.39 & 4.93 & - & 3.86 & 5.05 & - & 3.77 & 5.31 & - \\
\hline 個性 & 4.95 & 3.11 & ** & 5.23 & 2.78 & ** & 5.13 & 2.68 & ** \\
\hline
\end{tabular}


した。その上で，形態ごとに植物の様式の影響を検討した。

各大きさおよび距離ごとの植物（和風のモミジと洋風のクレス ト）の影響は次の通りであった。

大型，中型および小型のすべての大きさで，モミジの方が和風 であり, クレストの方が洋風で緑が豊かであると評価された（表一 9 )。潤い感の評価では, 小型ではクレストが有意にモミジを上 回った。しかし, クレストが緑量で高く評価された中型および大 型では, クレストとモミジの間で閏い感の差は見られなかった (表-9)。洗練性や美しさの外観評価では, 小型では, 両種の間 に差は無く, 中型および大型で, モミジがクレストを有意に上回っ た (表一 9$)$ 。また, 中型および大型では興味深いの評価でもモ ミジがクレストを有意に上回った（表-11，12）。さらに，大型 では，いずれの距離でも，モミジの方が開放的で，親しみやすく， 好ましいと評価された (表一12)。また, 設置距離の水準で様式 の影響が有意であったのは洗練性と潤いの 2 項目のみであった (デー夕略)。中および遠でモミジの洗練性の評価がクレストを上 回り, 遠でクレストの潤いの評価がモミジを上回った (データ略)。

モミジの方がクレストより和風であり, クレストの方がモミシ より洋風であると評価されたことは, 本実験での植物の様式の設 定が妥当であったことを示唆している。また, クレストはモミシ よりも緑が豊かであると評価された。実験に供した植物は, 種間

\begin{tabular}{|c|c|c|c|c|c|c|c|c|c|}
\hline \multirow{2}{*}{ 項目 } & \multicolumn{3}{|c|}{ 水準「小型」 } & \multicolumn{3}{|c|}{ 水準「中型」 } & \multicolumn{3}{|c|}{ 水準「大型」 } \\
\hline & 和風 & 洋風 & & 和風 & 洋風 & & 和風 & 洋風 & \\
\hline 美しい & 4.58 & 4.56 & ns & 4.92 & 4.26 & ** & 5.41 & 3.91 & *** \\
\hline 珗練 & 3.55 & 3.70 & ns & 4.10 & 3.77 & * & 4.65 & 4.04 & ** \\
\hline 和風洋風 & 5.46 & 3.42 & ** & 5.65 & 3.24 & ** & 5.86 & 2.89 & ** \\
\hline 潤い & 3.85 & 4.55 & ** & 4.62 & 4.64 & ns & 5.06 & 4.93 & ns \\
\hline 緑量感 & 3.50 & 4.53 & ** & 4.58 & 4.89 & * & 5.16 & 5.73 & ** \\
\hline 手軽な & 4.53 & 4.60 & ns & 3.92 & 4.28 & $* *$ & 3.35 & 3.25 & ns \\
\hline
\end{tabular}

表-10 距離の水準別の和風と洋風の平均値（小型）

\begin{tabular}{|c|c|c|c|c|c|c|c|c|c|}
\hline \multirow{2}{*}{ 項目 } & \multicolumn{3}{|c|}{ 水準「小型·近」 } & \multicolumn{3}{|c|}{ 水準「小型·中」 } & \multicolumn{3}{|c|}{ 水準「小型·遠」 } \\
\hline & 和風 & 洋風 & & 和風 & 洋風 & & 和風 & 洋風 & \\
\hline 好ましい & 5.01 & 4.83 & $\mathrm{~ns}$ & 4.43 & 4.56 & ns & 4.01 & 4.46 & * \\
\hline 安らぎ & 5.21 & 4.91 & ns & 4.40 & 4.73 & ns & 4.18 & 4.41 & ns \\
\hline 親しみ & 5.10 & 4.83 & ns & 4.25 & 4.69 & * & 4.11 & 4.51 & * \\
\hline 興味 & 5.03 & 4.53 & ** & 4.29 & 4.44 & ns & 4.01 & 4.09 & ns \\
\hline 開放性 & 4.99 & 4.53 & - & 5.16 & 4.80 & * & 5.38 & 5.03 & ${ }^{*}$ \\
\hline 均整 & 4.80 & 4.73 & $\mathrm{~ns}$ & 4.43 & 4.55 & ns & 4.13 & 4.70 & ** \\
\hline 個性 & 4.20 & 4.09 & - & 4.28 & 4.14 & - & 4.33 & 3.86 & - \\
\hline 公私 & 5.34 & 5.14 & - & 4.98 & 4.74 & - & 4.89 & 4.35 & ** \\
\hline
\end{tabular}

${ }^{*} \mathrm{p}<.05,{ }^{* *} \mathrm{p}<.01, \mathrm{n}=80$

表-11 距離の水準別の和風と洋風の平均值（中型）

\begin{tabular}{|c|c|c|c|c|c|c|c|c|c|}
\hline \multirow{2}{*}{ 項目 } & \multicolumn{3}{|c|}{ 水準「中型·近」 } & \multicolumn{3}{|c|}{ 水準「中型·中」 } & \multicolumn{3}{|c|}{ 水準「中型·遠」 } \\
\hline & 和風 & 洋風 & & 和風 & 洋風 & & 和風 & 洋風 & \\
\hline 好ましい & 4.63 & 4.18 & * & 4.78 & 4.38 & ns & 4.76 & 4.13 & ** \\
\hline 安らぎ & 4.68 & 4.34 & - & 4.80 & 4.56 & ns & 4.68 & 4.36 & ns \\
\hline 親しみ & 4.50 & 4.38 & ns & 4.70 & 4.39 & ns & 4.43 & 4.19 & ns \\
\hline 興味 & 4.73 & 4.28 & * & 4.56 & 4.08 & ** & 4.74 & 3.93 & ** \\
\hline 開放性 & 3.79 & 3.68 & - & 4.49 & 4.48 & ns & 4.89 & 4.96 & ns \\
\hline 均整 & 4.51 & 4.74 & - & 4.48 & 4.25 & - & 4.61 & 4.38 & ns \\
\hline 個性 & 4.20 & 4.03 & - & 4.30 & 3.98 & - & 4.06 & 4.01 & - \\
\hline 公私 & 4.81 & 4.54 & ns & 4.60 & 4.13 & * & 4.10 & 4.25 & is \\
\hline
\end{tabular}

表-12 距離の水準別の和風と洋風の平均值（大型）

\begin{tabular}{|c|c|c|c|c|c|c|c|c|c|}
\hline \multirow{2}{*}{ 項目 } & \multicolumn{3}{|c|}{ 水準「大型·近 } & \multicolumn{3}{|c|}{ 水準「大型·中」 } & \multicolumn{3}{|c|}{ 水準「大型·遠」 } \\
\hline & 和風 & 洋風 & & 和風 & 洋風 & & 和風 & 洋風 & \\
\hline 好ましい & 4.54 & 3.51 & ** & 5.41 & 3.76 & ** & 5.40 & 3.76 & ** \\
\hline 安らぎ & 4.49 & 3.66 & - & 5.31 & 4.03 & ** & 5.36 & 4.14 & ** \\
\hline 親しみ & 4.44 & 3.53 & ** & 4.95 & 3.90 & ** & 5.04 & 3.91 & ** \\
\hline 興味 & 4.94 & 3.89 & ** & 5.01 & 3.74 & ** & 5.19 & 3.91 & ** \\
\hline 開放性 & 2.79 & 2.21 & * & 4.64 & 3.15 & ** & 5.16 & 3.75 & ** \\
\hline 均整 & 4.43 & 4.46 & - & 4.78 & 4.66 & - & 5.01 & 4.49 & * \\
\hline 個性 & 4.18 & 3.98 & - & 4.14 & 3.74 & - & 4.34 & 4.00 & - \\
\hline 公私 & 3.88 & 3.33 & - & 3.59 & 3.28 & - & 3.68 & 3.31 & ns \\
\hline
\end{tabular}

で樹高を揃えるように配慮した。しかし，各植物の分枝の様式や 葉の大きさや枚数などの固有の特徵により, クレストの視野内の 緑の面積がモミジよりも大きくなった。それらの緑量差が評定者 の緑量感の評定にも影響を及ぼしたものと考えられた。一方，特 に中型や大型において，外観や安らぎ感などの評価で，モミジが クレストを上回った。浅海ら ${ }^{12)}$ は，ゴールドクレストを含む 16 種類の大型観葉植物の印象評価を SD 法により調査した。その結 果，クレス卜は，「高級な」や「さわやかな」，「あたたかい」， 「おしゃれな」,「心が落ち着く」,「置きたい」の項目で上位 3 位 に位置し，好ましい室内植物として評価された。本実験では，大 型のクレストの評価の平均值は, 美しい, 洗練 (表一-9), 安ら ぎ，親しみ，興味および親しみ（表－12）など，「どちらともい えない」を示す得点 4 前後の項目が多かった。一方, 大型のモミ ジの評価の平均值は, 特に中と遠で, 得点 5 以上を得た項目が多 く，かなり高いことが示された（表－9，12）。評価者にとって， モミジは，庭木や紅葉見物など日常的に接する機会が多いため, 大型のモミジが好意的に評価されたものと推測された。

形態ごとに植物の様式が印象に与える印象については次のよう に考察できる。

苔玉と鉢植えのいずれの形態でも，モミジを用いた方がより和 風に評価され, クレストを用いるとより洋風で, 緑が豊かである と評価された（表一13）。一方, 洗練性や美しさの外観評価では, 苔玉は, 植物の様式で評価が異なり, モミジ（和風）がクレスト （洋風）を有意に上回った（表－13）。しかし，鉢植えの場合には, 植物の様式による差は認められなかった（表一13）。さらに，好 ましさ, 安らぎおよび親しみの評価は, 苔玉の場合, すべての大 きさでモミジの評価が高かったのに対して，鉢植えでは，小型は クレスト，大型ではモミジの評価が高かった（表一14，15）。な お，設置距離と形態の水準で，様式による影響が見られたのは, 好ましさのみであり, 水準「苔玉」の全ての距離の水準において,

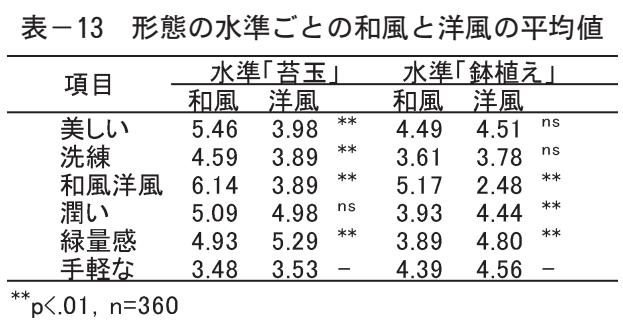

表-14 大きさの水準別の和風と洋風の平均値（苔玉）

\begin{tabular}{|c|c|c|c|c|c|c|c|c|c|}
\hline \multirow{2}{*}{ 項目 } & \multicolumn{9}{|c|}{ 水準「苔玉·小型」水準「苔玉·中型」水準「苔玉·大型」 } \\
\hline & 和風 & 洋風 & & 和風 & 洋風 & & 和風 & 洋風 & \\
\hline 好ましい & 5.18 & 4.53 & ** & 5.04 & 3.82 & ** & 5.30 & 3.44 & $* *$ \\
\hline 安らぎ & 5.29 & 4.66 & ** & 4.98 & 4.28 & ** & 5.09 & 3.81 & ** \\
\hline 親しみ & 5.00 & 4.42 & * & 4.70 & 3.94 & ** & 4.80 & 3.47 & ** \\
\hline & 5.29 & 4.68 & ** & 5.23 & 4.37 & ** & 5.43 & 4.09 & ** \\
\hline 開放性 & 5.23 & 4.63 & ** & 4.25 & 4.27 & ns & 4.00 & 3.29 & ** \\
\hline 均整 & 5.05 & 4.39 & - & 4.77 & 3.86 & - & 5.05 & 3.77 & - \\
\hline 個性 & 4.88 & 4.95 & ns & 4.75 & 5.23 & * & 4.70 & 5.13 & ns \\
\hline 公私 & 5.18 & 5.13 & - & 4.53 & 4.79 & - & 3.83 & 3.85 & - \\
\hline
\end{tabular}

表-15 大きさの水準別の和風と洋風の平均值（鉢植え）

\begin{tabular}{|c|c|c|c|c|c|c|c|c|c|}
\hline \multirow{2}{*}{ 項目 } & \multicolumn{9}{|c|}{ 水準「鉢植·小型」水準「鉢植·中型」水準「錸植·大型」 } \\
\hline & 和風 & 洋風 & & 和風 & 洋風 & & 和風 & 洋風 & \\
\hline 好ましい & 3.79 & 4.71 & ** & 4.40 & 4.63 & ns & 4.93 & 3.92 & \\
\hline 安らぎ & 3.90 & 4.71 & ** & 4.45 & 4.56 & ns & 5.02 & 4.08 & ** \\
\hline 親しみ & 3.98 & 4.93 & ** & 4.38 & 4.69 & ns & 4.82 & 4.09 & $k x$ \\
\hline & 3.59 & 4.02 & ns & 4.13 & 3.82 & ns & 4.67 & 3.60 & P* \\
\hline 開放性 & 5.13 & 4.93 & ns & 4.53 & 4.48 & ns & 4.39 & 2.78 & ** \\
\hline 均整 & 3.85 & 4.93 & - & 4.30 & 5.05 & - & 4.43 & 5.31 & - \\
\hline 個性 & 3.65 & 3.11 & ** & 3.63 & 2.78 & ** & 3.73 & 2.68 & ** \\
\hline 私 & 4.95 & 4.36 & - & 4.48 & 3.82 & - & 3.59 & 2.76 & - \\
\hline
\end{tabular}


表－16 様式の水準ごとの小型，中型および大型の平均值

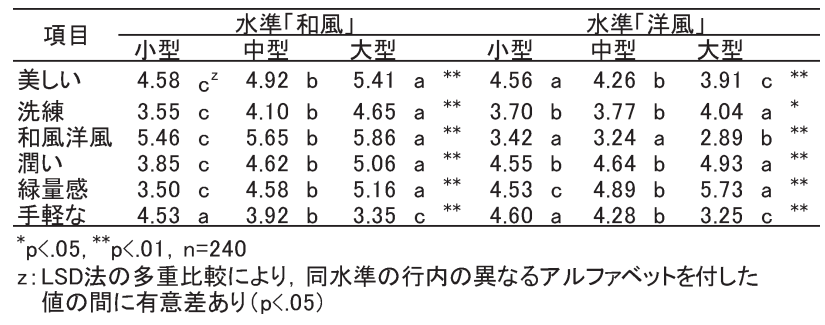

モミジに対する好ましさの評価がクレストに対する評価を上回っ た (デー夕略)。

和風洋風の判断や緑量の評価は, 双方の形態で共通していたこ とから、これらの評価は植物の種固有の印象が反映されたと推測 された。和風洋風の判断では, 苔玉が鉢植えより和風と評価され, モミジとクレストでは，モミジの方が和風であると評価された。 それらを組み合わせた場合にも，和風の評価得点平均值は，モミ ジ苔玉が最も高く, 次いで, モミジ鉢植え, クレスト苔玉, クレ スト鉢植えとなった。白石ら ${ }^{30)}$ は, 建築空間を対象に, 空間の構 成要素と「和風」・「洋風」という印象との関連を調査し, 構成 要素の持つ印象から全体の和風洋風の印象が構成されることを示 唆している。本実験でも, 植物の地下部の要素と植物の要素が組 み合わさり, 全体の和風洋風の評価が形成されたと考えられた。

形態よりも植物の様式が強く影響するとの傾向がみられた一方, 美しさや洗練性，好ましさ，安らぎおよび親しみなどの評価には， 形態ごとに様式の影響が異なった。美しさと洗練性では，苔玉で は，モミジで評価が高く，鉢植えでは様式による影響を受けなかっ た。さらに，安らぎなどの評価では，苔玉の場合にモミジ（和風） の評価が高く, 鉢植えの場合には, 大きさによって評価の高い様 式が異なった。小型鉢植えでクレスト（洋風）が，大型鉢植えで はモミジ（和風）の評価が高く，この結果は，植物そのものの評 価が反映されているのではないかと考えられた。一方，苔玉では， モミジで外観評価や安らぎなどの評価が高かったため, クレスト のような整形樹形の洋風植物よりも, モミジのような自然樹形の 和風植物の方が適していると示唆された。このことから, 特に苔 玉の場合に, 形態と植物の様式の調和・不調和が安らぎなどの評 価に影響を与えると考えられた。
以上に述べた結果から，苔玉にはモミジのような和風植物を用 いた場合に，美しさや洗練性などの評価が高く，鉢植えでは，植 物そのものの評価が反映されていると考えられたため, 植物の様 式の適・不適の評価はないように見られた。また本実験では，そ れぞれの様式に各 1 種の植物を用いて検討を行ったが, 様式ごと に複数種の植物を用いるなどのより詳細な検討が必要であると考 えられた。

（iii）室内植物の大きさが印象に与える影響

苔玉は，一般に小型が流通し，鉢植えは，中型から大型が主流 である。室内で用いる苔玉と鉢植えの適切な大きさは相互に異な る可能性があると考え, 形態ごとに大きさが印象に及ぼす影響を 検討した。大きさが異なることによって，質量や緑量が異なり， 植物の大きさそのものが印象に影響を及ぼすことも予測される。 そのため, まず様式および設置距離の水準で, 小型, 中型および 大型の評価得点の平均值を比較し, その特性を把握した。その上 で，各形態に適する大きさを検討した。

様式および設置距離の各水準で, 高く評価される大きさが異な る傾向を見せ（表－16 から 18）, 大きさの要因は，様式および設 置距離と複雑に関係していると理解された。そこで, 大きさと設 置距離との関係は, 次項で詳細に検討し, 本項では, 主に様式を 含めた大きさの影響の検討を行った。様式と大きさおよび設置距 離の 2 次の交互作用が有意であった項目に関しては, 設置距離 3 水準の内, 中庸の水準「中」のみで, 様式の水準ごとの大きさの 影響を検討した。大きさと設置距離との 1 次の交互作用が有意で あった項目でも，同様とした。設置距離の水準を平均した場合， モミジおよびクレストに共通して, 大型は緑が豊かであり, 潤い があり, 洗練されていると評価されたのに対し, 小型は他に比べ 手軽であり (表一 16$)$, 距離「中」のモミジ中・大型抢よびクレ スト大型に比べ開放的であると評価された（表-17,18）。潤いお よび緑量感の評価は, 距離「中」の場合でも, 大型が中型および 小型を上回り，中型が小型を上回った（デー夕略）。また，和風 洋風の項目では, モミジは, 大型になるほど和風の評価が高まり, クレストでは, 大型になるほど洋風の評価得点が増加した（表一 16)。一方, 美しさや好ましさ, 安らぎ, 親しみおよび興味では, モミジの場合は大型, そしてクレストの場合は小型で評価が高かっ た（表一16から 18）。

以上の結果より, 緑量感は, 植物の大きさに伴う物理的な緑量

表-17 距離の水準ごとの小型, 中型および大型の平均値（和風）

\begin{tabular}{|c|c|c|c|c|c|c|c|c|c|c|c|c|c|c|c|c|c|c|c|c|c|}
\hline \multirow{2}{*}{ 項目 } & \multicolumn{7}{|c|}{ 水準「和風·近」 } & \multicolumn{7}{|c|}{ 水準「和風·中」 } & \multicolumn{7}{|c|}{ 水準「和風·遠」 } \\
\hline & 小型 & & 中型 & & 大型 & & & 小型 & & 中型 & & 大型 & & & 小型 & & 中型 & & 大型 & & \\
\hline 好ましい & 5.01 & a & 4.63 & $\mathrm{~b}$ & 4.54 & $\mathrm{~b}$ & * & 4.43 & b & 4.78 & $\mathrm{~b}$ & 5.41 & $a$ & ** & 4.01 & c & 4.76 & $b$ & 5.40 & a & ** \\
\hline 安らぎ & 5.21 & a & 4.68 & $b$ & 4.49 & $b$ & $* *$ & 4.40 & c & 4.80 & $b$ & 5.31 & a & $* *$ & 4.18 & c & 4.68 & $b$ & 5.36 & a & ** \\
\hline 親しみ & 5.10 & a & 4.50 & $b$ & 4.44 & $b$ & $* *$ & 4.25 & b & 4.70 & a & 4.95 & a & $* *$ & 4.11 & $b$ & 4.43 & $b$ & 5.04 & a & ** \\
\hline 興味 & 5.03 & & 4.73 & & 4.94 & & ns & 4.29 & $b$ & 4.56 & $b$ & 5.01 & a & ** & 4.01 & c & 4.74 & $b$ & 5.19 & $a$ & ** \\
\hline 開放性 & 4.99 & a & 3.79 & b & 2.79 & c & $* *$ & 5.16 & a & 4.49 & $b$ & 4.64 & $b$ & $* *$ & 5.38 & a & 4.89 & $b$ & 5.16 & $a b$ & $*$ \\
\hline 均整 & 4.80 & & 4.51 & & 4.43 & & ns & 4.43 & & 4.48 & & 4.78 & & ns & 4.13 & c & 4.61 & $b$ & 5.01 & $a$ & ** \\
\hline 個性 & 4.20 & & 4.20 & & 4.18 & & - & 4.28 & & 4.30 & & 4.14 & & - & 4.33 & & 4.06 & & 4.34 & & - \\
\hline 公私 & 5.34 & & 4.81 & & 3.88 & & - & 4.98 & & 4.60 & & 3.59 & & - & 4.89 & a & 4.10 & b & 3.68 & c & ** \\
\hline
\end{tabular}

${ }^{*} \mathrm{p}<.05,{ }^{* *} \mathrm{p}<.01, \mathrm{n}=80$

表－18 距離の水準ごとの小型, 中型および大型の平均値（洋風）

\begin{tabular}{|c|c|c|c|c|c|c|c|c|c|c|c|c|c|c|c|c|c|c|c|c|c|}
\hline \multirow{2}{*}{ 項目 } & \multicolumn{7}{|c|}{ 水準「洋風·近」 } & \multicolumn{7}{|c|}{ 水準「洋風·中」 } & \multicolumn{7}{|c|}{ 水準「洋風·遠」 } \\
\hline & 小型 & & 中型 & & 大型 & & & 小型 & & 中型 & & 大型 & & & 小型 & & 中型 & & 大型 & & \\
\hline 好ましい & 4.83 & a & 4.18 & b & 3.51 & c & ** & 4.56 & a & 4.38 & a & 3.76 & $b$ & ** & 4.46 & a & 4.13 & $a b$ & 3.76 & $b$ & ** \\
\hline 安らぎ & 4.91 & a & 4.34 & $b$ & 3.66 & c & ** & 4.73 & a & 4.56 & a & 4.03 & b & ** & 4.41 & & 4.36 & & 4.14 & & ns \\
\hline 親しみ & 4.83 & a & 4.38 & b & 3.53 & c & ** & 4.69 & a & 4.39 & a & 3.90 & $b$ & ** & 4.51 & a & 4.19 & $a b$ & 3.91 & b & ** \\
\hline 興味 & 4.53 & a & 4.28 & $a b$ & 3.89 & b & ** & 4.44 & a & 4.08 & $a b$ & 3.74 & b & ** & 4.09 & & 3.93 & & 3.91 & & ns \\
\hline 開放性 & 4.53 & a & 3.68 & $b$ & 2.21 & c & ** & 4.80 & a & 4.48 & a & 3.15 & $b$ & ** & 5.03 & a & 4.96 & a & 3.75 & $b$ & $* *$ \\
\hline 均整 & 4.73 & & 4.74 & & 4.46 & & $\mathrm{~ns}$ & 4.55 & & 4.25 & & 4.66 & & ns & 4.70 & & 4.38 & & 4.49 & & ns \\
\hline 個性 & 4.09 & & 4.03 & & 3.98 & & - & 4.14 & & 3.98 & & 3.74 & & - & 3.86 & & 4.01 & & 4.00 & & - \\
\hline 公私 & 5.14 & a & 4.54 & b & 3.33 & c & ** & 4.74 & a & 4.13 & b & 3.28 & c & ** & 4.35 & a & 4.25 & a & 3.31 & $b$ & ** \\
\hline
\end{tabular}

${ }^{* *} \mathrm{p}<.01, \mathrm{n}=80$ 
の増加に従って肯定的に評価が向上すると考えられた。また, 潤 い感は, 大型になるほど緑量感とともに評価が高くなると推測さ れた。

洗練性はいずれの植物でも大型で高く評価され，大きさの影響 が強いと考えられた。また, 和風洋風の評価では, 大型になるほ ど，モミジはより和風に，クレストの場合はより洋風に評価され ており，植物の大きさが増すほど，植物固有の特性をよりはっき りと認識できるようになるのでないかと推測した。一方, 美しさ や安らぎ感などの評価は, 様式ごとに高く評価される大きさが異 なった。この結果は, 植物種により, 好まれる（評価される）大 きさが異なることを示唆している。

以上の結果から, 室内に設置する植物の大きさは, 手軽さや開 放性などの容積（大きさ）に関連が深い印象だけでなく, 外観評 価や和風洋風の判断, 好ましさなどの多くの印象に影響を与える ことが明らかになった。今後は, 植物を設置する居室の大きさと の関連などを明らかにし, 適切な設置密度などを検討することが 課題であると考えられた。

形態掞よび植物ごとに大きさの影響を検討した。その結果, 苔 玉と錸植えに共通して, 大型が緑が豊かで潤いがあり, 洗練され ており，小型は手軽で（表－19）開放的であると評価された（表一 20, 21)。

美しさでは, 苔玉は小型の方が, 鉢植えは中型もしくは大型の 評価が高かった（表一19）。

室内植物としてのアメニティ性を示すと考えられる好ましさや 安らぎ, 親しみおよび興味の項目では, クレストの苔玉で, 小型 の評価が高かったが，モミジの苔玉は大きさによる差が見られず， じの大きさでも高く評価された（表一20）。またモミジの鉢植え では，大型の評価が高いのに対して，クレストの鉢植えでは小型 もしくは中型の評価が高かった（表－21）。

緑量感や潤い感, 洗練性, 手軽さおよび 開放性では, 様式別で比較した際と, 形態 別で比較した場合に同様の傾向を示した。 様式あるいは形態を平均した場合にも大き さの影響が維持されたと考えることができ， 様式や形態の特性よりも大きさが強く影響 する項目であると考えられた。一方，様式 ごとに分析した場合には, 大きさが和風洋 風の評価に影響したが, 形態ごとにみると, 大きさは影響しなかった。形態の影響の箇 所でも述べたように, 和風洋風の評価には, 様式の影響が強く, 様式で見た場合に, 形 態や大きさによる影響が検出されるが，様 式を区別せずに平均すると，分散が拡大さ れるため, 有意差が検出されないのではな いかと考えられた。

美しさの評価に対する大きさの影響は, 形態の違いによって傾向が異なった。さら に, 好ましさ, 安らぎ感の評価は, 様式や 形態ごとに，大きさの影響が異なった。形 態ごとに様式の影響を検討した際にも述へ たように，苔玉にはモミジが適していると 考えられ，そのモミジを用いた場合には， 苔玉は大きさに拘わらず，好ましさや安ら ぎ感で高く評価された。一方, 苔玉の材料 としての適性でモミジに劣るクレストでは, 大きさの影響がみられ，小型ではこれらの 項目の評価が高かった。洋風の認識が強い 大型や中型よりも, 小型の場合に, クレス

${ }^{*} \mathrm{p}<.05,{ }^{* *} \mathrm{p}<.01, \mathrm{n}=80$
表-19 形態の水準ごとの小型, 中型および大型の平均值

\begin{tabular}{|c|c|c|c|c|c|c|c|c|c|c|c|c|c|c|}
\hline \multirow{2}{*}{ 項目 } & \multicolumn{7}{|c|}{ 水準「苔玉」 } & \multicolumn{7}{|c|}{ 水準「鉢植え」 } \\
\hline & 小型 & & 中型 & & 大型 & & & 小型 & & 中型 & & 大型 & & \\
\hline 美しい & 4.99 & $a$ & 4.55 & $b$ & 4.60 & b & ** & 4.15 & b & 4.62 & a & 4.72 & a & ** \\
\hline 洗練 & 4.10 & b & 4.08 & b & 4.55 & a & ** & 3.15 & c & 3.79 & b & 4.14 & a & ** \\
\hline 和風洋風 & 5.07 & & 5.05 & & 4.93 & & - & 3.81 & & 3.84 & & 3.82 & & - \\
\hline 潤い & 4.81 & b & 4.96 & b & 5.33 & a & ** & 3.59 & c & 4.30 & b & 4.66 & a & ** \\
\hline 緑量感 & 4.51 & c & 5.20 & b & 5.62 & a & ** & 3.51 & c & 4.26 & b & 5.27 & a & ** \\
\hline 手軽な & 4.05 & a & 3.47 & $b$ & 2.99 & $\mathrm{c}$ & ** & 5.08 & $a$ & 4.73 & $b$ & 3.62 & c & $* *$ \\
\hline
\end{tabular}

表－20 様式の水準別の小型, 中型および大型の平均値（苔玉）

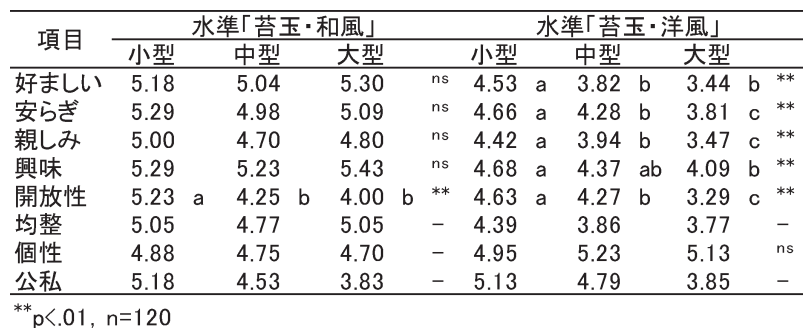

表-21 様式の水準別の小型, 中型および大型の平均值（鉢植え）

\begin{tabular}{|c|c|c|c|c|c|c|c|c|c|c|c|c|c|c|}
\hline \multirow{2}{*}{ 項目 } & \multicolumn{7}{|c|}{ 水準「鉢植え·和風」 } & \multicolumn{7}{|c|}{ 水準「鉢植え・洋風」 } \\
\hline & 小型 & & 中型 & & 大型 & & & 小型 & & 中型 & & 大型 & & \\
\hline 好ましい & 3.79 & c & 4.40 & b & 4.93 & a & ** & 4.71 & a & 4.63 & a & 3.92 & b & $*$ \\
\hline 安らぎ & 3.90 & c & 4.45 & b & 5.02 & $a$ & ** & 4.71 & a & 4.56 & a & 4.08 & b & ** \\
\hline 親しみ & 3.98 & c & 4.38 & b & 4.82 & a & ** & 4.93 & a & 4.69 & a & 4.09 & b & 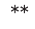 \\
\hline 興味 & 3.59 & c & 4.13 & b & 4.67 & a & ** & 4.02 & a & 3.82 & $a b$ & 3.60 & b & \\
\hline 開放性 & 5.13 & a & 4.53 & b & 4.39 & b & ** & 4.93 & a & 4.48 & $b$ & 2.78 & $\mathrm{c}$ & Ft \\
\hline 均整 & 3.85 & & 4.30 & & 4.43 & & - & 4.93 & & 5.05 & & 5.31 & & 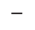 \\
\hline 個性 & 3.65 & & 3.63 & & 3.73 & & - & 3.11 & a & 2.78 & b & 2.68 & b & . \\
\hline 公私 & 4.95 & & 4.48 & & 3.59 & & - & 4.36 & & 3.82 & & 2.76 & & - \\
\hline
\end{tabular}

${ }^{*} \mathrm{p}<.05,{ }^{* *} \mathrm{p}<.01, \mathrm{n}=120$

表一22 大きさの水準ごとの近, 中および遠の平均値

\begin{tabular}{|c|c|c|c|c|c|c|c|c|c|c|c|c|c|c|c|c|c|c|c|c|}
\hline \multirow{2}{*}{ 項目 } & \multicolumn{6}{|c|}{ 水準「小型」 } & \multicolumn{6}{|c|}{ 水準「中型」 } & & \multicolumn{7}{|c|}{ 水準「大型」 } \\
\hline & 近 & & 中 & & 遠 & & 近 & & 中 & & 遠 & & & 近 & & 中 & & 遠 & & \\
\hline 美しい & 4.95 & a & 4.46 & $b$ & 4.30 & $\mathrm{~b}^{* *}$ & 4.67 & & 4.58 & & 4.51 & & ns & 4.57 & & 4.71 & & 4.71 & & ns \\
\hline 洗練 & 3.66 & & 3.66 & & 3.56 & - & 4.05 & & 3.93 & & 3.83 & & - & 4.21 & & 4.38 & & 4.45 & & - \\
\hline 潤い & 4.64 & a & 4.31 & $b$ & 3.64 & $c^{* *}$ & 4.91 & a & 4.71 & a & 4.26 & b & ** & 5.06 & & 5.01 & & 4.92 & & ns \\
\hline 緑量感 & 4.43 & a & 4.09 & b & 3.52 & $c^{* *}$ & 4.87 & a & 4.84 & a & 4.49 & b & ** & 5.59 & a & 5.48 & a & 5.26 & $b$ & ** \\
\hline 手軽な & 4.62 & & 4.51 & & 4.57 & - & 4.08 & & 4.01 & & 4.22 & & - & 3.17 & & 3.28 & & 3.46 & & - \\
\hline
\end{tabular}

表一23 大きさの水準ごとの近, 中および遠の平均值（和風）

\begin{tabular}{|c|c|c|c|c|c|c|c|c|c|c|c|c|c|c|c|c|c|c|c|c|c|}
\hline \multirow{2}{*}{ 項目 } & \multicolumn{6}{|c|}{ 水準「和風 - 小型」 } & & \multicolumn{7}{|c|}{ 水準「和風 - 中型」 } & \multicolumn{7}{|c|}{ 水準「和風·大型」 } \\
\hline & 近 & & 中 & & 遠 & & & 近 & & 中 & & 遠 & & & 近 & & 中 & & 遠 & & \\
\hline 好ましい & 5.01 & a & 4.43 & b & 4.01 & $\mathrm{c}^{3}$ & & 4.63 & & 4.78 & & 4.76 & & ns & 4.54 & b & 5.41 & a & 5.40 & a & ** \\
\hline 安らぎ & 5.21 & a & 4.40 & b & 4.18 & $b$ & & 4.68 & & 4.80 & & 4.68 & & ns & 4.49 & b & 5.31 & a & 5.36 & a & ** \\
\hline 親しみ & 5.10 & a & 4.25 & b & 4.11 & $b$ & & 4.50 & & 4.70 & & 4.43 & & ns & 4.44 & b & 4.95 & a & 5.04 & a & ** \\
\hline 興味 & 5.03 & a & 4.29 & b & 4.01 & $b^{*}$ & & 4.73 & & 4.56 & & 4.74 & & ns & 4.94 & & 5.01 & & 5.19 & & ns \\
\hline 開放性 & 4.99 & b & 5.16 & $a b$ & 5.38 & $a^{\prime}$ & & 3.79 & c & 4.49 & b & 4.89 & a & ** & 2.79 & c & 4.64 & b & 5.16 & a & ** \\
\hline 均整 & 4.80 & a & 4.43 & b & 4.13 & c & & 4.51 & & 4.48 & & 4.61 & & ns & 4.43 & b & 4.78 & a & 5.01 & a & ** \\
\hline 個性 & 4.20 & & 4.28 & & 4.33 & & & 4.20 & & 4.30 & & 4.06 & & - & 4.18 & & 4.14 & & 4.34 & & - \\
\hline 公私 & 5.34 & & 4.98 & & 4.89 & & & 4.81 & a & 4.60 & $a$ & 4.10 & & $* *$ & 3.88 & & 3.59 & & 3.68 & & - \\
\hline
\end{tabular}

表－24 大きさの水準ごとの近, 中および遠の平均値（洋風）

\begin{tabular}{|c|c|c|c|c|c|c|c|c|c|c|c|c|c|c|c|c|c|c|c|c|}
\hline \multirow{2}{*}{ 項目 } & \multicolumn{7}{|c|}{ 水準「洋風・小型」 } & \multicolumn{7}{|c|}{ 水準「洋風・中型」 } & \multicolumn{6}{|c|}{ 水準「洋風·大型」 } \\
\hline & 近 & & 中 & & 遠 & & & 近 & & 中 & & 遠 & & & 近 & & 中 & & 遠 & \\
\hline 好ましい & 4.83 & & 4.56 & & 4.46 & & ns & 4.18 & & 4.38 & & 4.13 & & ns & 3.51 & & 3.76 & & 3.76 & n \\
\hline 安らぎ & 4.91 & a & 4.73 & a & 4.41 & b & ** & 4.34 & & 4.56 & & 4.36 & & ns & 3.66 & b & 4.03 & a & 4.14 & $a^{*}$ \\
\hline 親しみ & 4.83 & & 4.69 & & 4.51 & & ns & 4.38 & & 4.39 & & 4.19 & & ns & 3.53 & b & 3.90 & a & 3.91 & a \\
\hline 興味 & 4.53 & a & 4.44 & a & 4.09 & b & ** & 4.28 & & 4.08 & & 3.93 & & - & 3.89 & & 3.74 & & 3.91 & - \\
\hline 開放性 & 4.53 & b & 4.80 & $a b$ & 5.03 & a & ** & 3.68 & c & 4.48 & b & 4.96 & a & ** & 2.21 & c & 3.15 & b & 3.75 & a \\
\hline 均整 & 4.73 & & 4.55 & & 4.70 & & ns & 4.74 & a & 4.25 & b & 4.38 & b & * & 4.46 & & 4.66 & & 4.49 & $\mathrm{n}$ \\
\hline 個性 & 4.09 & & 4.14 & & 3.86 & & - & 4.03 & & 3.98 & & 4.01 & & - & 3.98 & & 3.74 & & 4.00 & - \\
\hline 公私 & 5.14 & a & 4.74 & b & 4.35 & & ** & 4.54 & & 4.13 & & 4.25 & & ns & 3.33 & & 3.28 & & 3.31 & $n$ \\
\hline
\end{tabular}


トが苔玉の材料としての適性が高いと判断されたと考えられた。 鉢植えでは，モミジは大型，クレストは小型もしくは中型で評価 が高かった。この結果は, 中に設置した植物ごとの大きさの影響 を比較した結果と類似し, 各植物の特徴を反映していると判断で きる。一方, 苔玉は, ふさわしい植物を用いると, 大型でも評価 されるが, 小型の方が美しく, 手軽であると評価され, 洋風の植 物では, 大型は評価が低く, 小型の場合に評価が肯定側に傾くと 考えられた。

以上の結果として, 室内植物の形態ごとの大きさの印象への影 響は次のように整理された。苔玉は小型ほど美しく, 和風苔玉は 大きさに拘わらず安らぎ感や親しみやすさ，好ましさなどの室内 植物としての高いアメニティ性を示したのに対して, 洋風苔玉は 大型ほどアメニティ性が低下した。一方, 鉢植えは, 大型ほど美 しいと評価され, アメニティ性の評価は, 植物の特徵を反映し, モミジは大型，クレストは小型で評価が高かった。

(iv) 設置距離が印象に与える影響

設置距離が印象に与える影響を検討した。和風洋風の評価では, 近（4.51）が中（4.36）および遠（4.39）に設置した場合に比へ， 和風と評価された $(\mathrm{n}=480)$ 。形態や様式の各水準で, 距離ごと の評価得点平均值を比較したが, 有意差がみられた項目は, 少な かった (デー夕略)。そこで, 距離と最も関連があると考えられ る大きさの各水準で距離の影響を比較した。その結果, 大きさの 3 水準いずれの場合にも，近で緑が豊かであり，遠で開放的であ ると評価された（表一22）。その他の評価は，大きさにより異な り, 小型では, 近の方が, 美しく (表-22), 安らぎ, 興味の評 価が高かった（表一23，24）。また, 同じく小型で, モミジの場 合, 近の方が好ましく, 親しみやすく, 均整がとれており（表一 23), クレストの場合, 近の方が私的であると評価された（表一 24)。中型では, 近で, より潤い感があり（表一-22）, モミジの場 合，遠に比べ近や中で私的であると評価されたが（表一23），そ の他の項目には有意な差が見られなかった。大型では, 中もしく は遠で，安らぎおよび親しみの評価が高く（表一23，24），モミ ジの場合, 中もしくは遠が, 好ましく, 均整がとれていると評価 された（表一23）。

以上の結果から, 緑量感は, 評定者と植物との距離が近いほど 高まると判断された。すべての大きさの水準で有意差が認められ たが, その差は, 植物が大きくなるほど減少し, 大型植物は, 遠 にあっても緑量感は高いと判断された。一方, 小型植物は, 距離 水準間で平均值の差が大きく, 遠に設置した場合に緑量感が低い ことが示唆された。開放性も，いずれの大きさでも遠の評価が高 かったが, 中および近との差は緑量感とは逆に, 大型になるほど 大きかった。大型植物を近に設置した場合, 圧迫感が強くなるこ とが要因と考えられ，大型植物を身近に設置することは望ましく ないと判断された。

安らぎや興味, 親しみなどの評価は, 大きさにより影響が異なっ た。中型では, 評価に対する距離の影響が小さく, 目的（緑量や 開放性の確保など）に応じていずれの距離に設置することも可能 であると考えられた。一方, 小型では, 近で評価が高かった。小 型の近では, 遠に比へ開放性は有意に低いものの, 平均值から判 断すると, 小型であることにより, 圧迫側の評価にはならず, 得 点 4 以上の開放性は維持できていると考えることができた（表一 23, 24)。その結果, 近で安らぎや興味, 親しみの評価が妨げら れなかったものと考えられた。大型では, 近で緑量感が高いが, 同時に圧迫感が非常に強く, また, 前述のように, 中・遠でも高 い緑量感が得られた。そのため大型は，遠もしくは中に適してい ると判断された。都市公園内の樹木を対象とした視距離による樹 木の見え方および感じ方の調査 ${ }^{25}$ で, 対象が同一であっても, 視 距離によって印象が変化することが明らかにされている。本実験
では, 室内という限られた空間内でも, 評定者と室内植物との距 離は，緑量感や潤いおよび開放性などに影響を与え，さらには， 大きさとの関連によって, 距離が快適性に影響を与えられること が示唆された。

\section{4.まとめ}

これまで，室内植物の印象については，種や配置方法による影 響の検討が行われてきた。しかし現在，室内植物は大きさや形態 などの点で多様化しており, それらの多様な室内植物に対する人々 の心理的影響の検討が課題であると考えられた。多様性の要因の 内の一つであると考えられる植物の形態による心理的評価への影 響の検討は，これまで行われてこなかったが，今回新たに，苔玉， 鉢植えという植物の形態間で, 緑量感や和風洋風の認識, 美しさ, 好ましさおよび親しみやすさなどの印象評価に差が生じうること が示された。日本独特の庭園景観の中でも，コケまたは水のある 庭園に癒される傾向があることが報告されている ${ }^{21}$ 。さらに, 水 よりもコケに湿った印象を受け，しっとりした感じや湿った感じ の庭園景観に癒される傾向が示された ${ }^{21}$ 。本研究でも, 苔玉は鉢 植えに比へ，緑が豊かであると評価されると同時に，潤いがある と評価された。また，モミジを用いた場合，小型および中型の苔 玉は錰植えよりも安らぎがあると評価された。苔玉による安らぎ 感の創出の一要因として, コケの潤い感が影響を及ぼしている可 能性が推測された。また，苔玉と鉢植えの形態ごとに用いる植物 の様式 (和風および洋風) の違いが美しさや洗練, 親しみやすさ や安らぎなどの評価に差を生じさせると考えられた。

室内空間で同種の植物の大きさを変化させてその印象を比較し た研究も見られなかったが, 本研究では, 新たに, 大中小の植物 を用い, 大きさが, 緑量感や潤い, 手軽さなどの印象に影響しう ることを明らかにした。さらに，大きさが増すほど，植物の和風 洋風の印象はより鮮明になることやモミジは大型, 一方, クレス 卜は小型で好ましさが高く評価されることが示唆された。そして, 例えば，美しさでは，苔玉は小型で，鉢植えは大型で評価が高い ように，形態ごとに高く評価される大きさも異なると判断された。 住宅の外構の庭に用いられる植物では, 小さいものよりも大きい ものの方がより住宅の価值を高めるとの報告 ${ }^{23)}$ がある。今回の調 查を行った室内空間では, 形態によっては, 小型の植物に対する 評価が高いことが示された。植物が身近にある条件下での新たな 評価と考えられる。

これまで，室内空間で大きさの異なる植物を設置距離を変えて， その印象を検討した研究は見られなかったが，今回の実験では, それぞれの大きさごとに評価の高い設置距離が異なることが示さ れた。すなわち，小型を手の届く近い範囲に設置した場合 $(0.5$ $\mathrm{m})$, それより離れた場所に設置した場合に比へ，緑量感や潤い などの評価が高いだけでなく, 美しさや安らぎ等の評価も向上し た。また, 中型の場合には, 緑量感の向上や開放性の確保などの 目的に応じて, $0.5 \mathrm{~m}$ から $3 \mathrm{~m}$ までの範囲内では, どの距離にも 利用可能であると考えられた。一方，大型の場合には， $0.5 \mathrm{~m}$ や $1.5 \mathrm{~m}$ に比へ， $3 \mathrm{~m}$ 離れた場所に設置する場合に, 開放性が確保 され， $1.5 \mathrm{~m}$ 以上離れた場所に設置すると，親しみや安らぎ等の 評価も高まることが示された。公園緑地のイメージ評価では, 自 然性の評価は，近距離で高いことが示されている。一方，自然性 が高くても, 植栽密度が高いとその圧迫感から快適性が低く評価 されることも明らかにされている311。本研究では, 室内の限られ た空間内で木本植物に対する評価を調査した。緑地とは条件が異 なったが, 緑地の場合と同様に, 緑量感は距離の影響を受け, 近 距離に設置された緑量の多い大型植物は, 圧迫感を生じさせるこ ととなり, 安らぎ感などが低下した。室内でも適度な植栽密度の 確保が快適性を得るために重要であると考えられた。 
これまで大型の鉢植え観葉植物を用いて知見の蓄積が行われて きた。今回は，それ以外の中，小型の観葉植物や苔玉をも用いる ことで, 新たに, オフィス等の比較的単調で無機質な空間で植物 の形態や大きさ, 設置距離なども室内植物の印象評価に影響を及 ぼしうることを実験により具体的に明らかにすることができた。 オフィス等での室内植物利用の際には, 苔玉には整形式樹形を持 つゴールドクレストのような洋風植物よりも自然樹形を持つイロ 八モミジのような和風の植物を用いるようにする，あるいは，小 型の植物は身近に, 大型の植物は圧迫感を与えないように離れた 場所に設置するように心がけるなど, 各要因の適切な組み合わせ に配慮することが求められると考えられる。そして, オフィス等 に設置された小型の苔玉でも, 和風の植物を用い, 身近に設置す ることで, 人々に安らぎや親しみの印象を与えることが可能であ ることが明らかになった。なお, 今回の実験は, 様式を要因とし た際に各 1 種のみの植物を選定して行ったが, 植物の様式の影響 に対する知見に普遍性を持たせるためには, それぞれの様式に複 数種の植物を用いて検討を行う必要があると考えた。また今回は, パラメトリック検定の分散分析により, 被験者内計画の 4 要因の 影響を分析したが，検定方法によっては今回の結果と異なる可能 性むありうる。今回の結果の再現性については, 今後, 知見の蓄 積により検証することが求められる。

\section{謝辞}

本研究での統計的解析について, 京都府立大学石田正浩准教授 には有益な指導，助言を賜った。記して謝意を表する。

\section{引用文献}

1 ） O.F. ボルノー（森田孝・大塚恵一訳）（1988）：問いへの 教育 増補版 : 川島書店, $315 \mathrm{pp}$

2) 下村孝（2007）：都市における緑の効用一身近な緑がもたら す心身の健康と人間らしい生活 - : Urban - Advance 44, 13-21

3 ）長谷川祥子・下村孝（2008）：室内植物として利用される苔 玉の利用の実態および評価に関するアンケート調査 : ランド スケープ研究 71(5), 821-826

4 ）下村孝・黒宮ゆかり・上町あずさ（2007）：家庭における室 内緑化植物の利用実態之利用者の意識：人間 - 植物関係学会 誌 6(2), 31-39

5 ) 三宅晋司（2001）：職場における観葉植物一そのイメージと 効用-: 人間工学 37 特別号, $570-571$

6 ）下村孝・中尾幸彦・筒井旬子（1988）：商業空間におけるイ ンテリア材料としての観葉植物の利用と役割：造園雑誌 51 (5), 114-119

7 ) Manaker, G. H. (1987): Interior plantscapes: installation, maintenance, and management: Prentice-Hall, 324pp

8 ) 浅海英記・仁科弘重・塚西圭・増井典良・橋本康（1994）： 観葉植物が室内の温熱環境および温熱快適性に及ぼす影響： 日本建築学会計画系論文集 464, 39-46

9 ）仁科弘重・浅海英記・塚西圭（1993）：植物を用いたアメ二 ティ（グリーンアメニティ）に関する研究（その2. 観葉植 物が室内の温熱環境に及ぼすアメニティ効果の実証的検討）： 日本建築学会大会学術講演梗概集，1333-1334

10) Orwell, R., R. Wood, M. Burchett, J. Tarran and F. Torpy (2006): The potted-plant microcosm substantially reduces indoor air VOC pollution: II. Laboratory study: Water, Air, and Soil Pollution 177, 59-80

11）水野敬三・鈴木邦臣・長谷見雄二（1989）：室内の観葉植物 の火災時に抢ける有用性に関する研究: 日本建築学会大会学
術講演梗概集, 981-982

12）浅海英記・仁科弘重・ 難波亮子・増井典良・橋本康（1995）： 観葉植物の印象の評価, および, 観葉植物を配置した室内の 居住者心理の SD 法による評定：植物工場学会誌 7(1), 3445

13）浅海英記・仁科弘重・中村博文・増井典良・橋本康（1995）： 植物を見ることがVDT 作業に伴う視覚疲労に及ぼす影響： 植物工場学会誌 7(3), 138-143

14) Lohr, V. I. and C. H. Pearson-Mims (2000): Physical discomfort may be reduced in the presence of interior plants: HortTechnology 10(1), 53-58

15) Dijkstra, K., M. E. Pieterse and A. Pruyn (2008): Stress-reducing effects of indoor plants in the built healthcare environment: Preventive Medicine 47, 279-283

16) Fjeld, T. (2000): The effect of interior planting on health and discomfort among workers and school children: HortTechnology 10(1), 46-52

17）岩崎寛・井上紗代・山本聡（2006）：インテリア雑貨として の観葉植物の生育特性に関する研究 : ランドスケープ研究 69(5), 447-450

18）水野隆（2008）：ライフスタイルショップでのインテリアプ ランツ：グリーン情報 413，21

19）サンケイリビング新聞社（2009）：デスクの上の植物が癒し \&効率 up に : シティリビング 1007,24

20）仁科弘重・山本直樹 - 高山弘太郎 - 竹野淳一・臼田和正 （2007）：観葉植物がオフィスワーカーに及ぼすアメニティ 効果の解析: 日本生物環境工学会設立大会講演要旨, 228229

21）谷口小百合・張格瑋・相田明・鈴木誠（2003）：庭園景から 受ける癒しのイメージに関する調查研究 : 東京農大農学集報 48(3), 115-127

22）伊達けい子・秋元治久監修（2003）：草もの・木ものすて きなミ二盆栽：主婦と生活社, $111 \mathrm{pp}$

23) Behe, B., J. Hardy, S. Barton, J. Brooker, T. Fernandez, C. Hall, J. Hicks, R. Hinson, P. Knight, R. McNiel, T. Page, B. Rowe, C. Safley and R. Schutzki (2005): Landscape plant material, size, and design sophistication increase perceived home value: J. Environ. Hort. 23(3), 127-133

24) Bringslimark, T., T. Hartig and G.G. Patil (2007): Psychological benefits of indoor plants in workplace: HortScience 42(3), 581-587

25）横川洋也・鈴木誠・進士五十八（1998）：視距離による樹木 の見え方・感じ方に関する研究 : ランドスケープ研究 61(5), 609-612

26）上原敬二（1926）：日本式庭園形式の通則：造園学雑誌 2(4), 316-325

27）飯島亮・安赫俊比古（1984）：庭木と緑化樹 2 落葉高木・低 木類：誠文堂新光社, $338 \mathrm{pp}$

28）柴田忠裕（1999）：コニファーズブック：グリーン情報, $176 \mathrm{pp}$

29）塩見邦雄・金光義弘・足立明久編（1985）：心理検査・測定 ガイドブック：ナカニシヤ出版, $242 \mathrm{pp}$

30）白石光昭（2007）：室内空間の印象評価に空間の構成要素が 与える影響 : デザイン学研究発表大会概要集 54, 284-285

31）三浦利夫・飛岡次郎（1993）：緑空間の心理的機能と評価法 に関する研究：造園雑誌 56(5), 235-240

(2010.1.30 受付, 2011.1.31 受理) 